\author{
Mikel Burley \\ m.m.burley@1eeds.ac.uk
}

\title{
"We Are Human Beings, and We Value Human Life": Glock and Diamond on Mental Capacities and Animal Ethics
}

\section{Abstract}

How should a philosophical inquiry into the moral status of (nonhuman) animals proceed? Many philosophers maintain that by examining the "morally relevant" psychological or physiological capacities possessed by the members of different species, and comparing these with similar capacities possessed by human beings, the moral status of the animals in question can be established. Others contend that such an approach runs into serious moral and conceptual problems, a crucial one being that of how to give a coherent account of the natural sense of concern for profoundly cognitively impaired human beings if moral status is assumed to depend on features that centrally include cognitive capacities. The present article discusses this debate with reference to Wittgenstein-influenced philosophers whose respective approaches, on the face of it, diverge dramatically. With a primary focus on Hans-Johann Glock and Cora Diamond, and a secondary focus on recent work by Alice Crary, I argue that, despite an overt disavowal of the kind of approach favoured by Diamond and Crary, Glock's affirmation that we simply do "value human life" brings him closer to that approach than he acknowledges.

In a series of articles and book chapters, Hans-Johann Glock has argued, against certain philosophers who regard all or most psychological or mental concepts as applying exclusively to human beings, that many animals possess capacities that warrant the application of such concepts to them as well. ${ }^{1}$ The majority of his work on this topic does not explore

\footnotetext{
1 Relevant contributions include Glock 2010, 2012, 2016, 2017a, 2017b, 2018. As Glock observes, the most radical denial that psychological or mental concepts apply to animals comes from lingualism, which is the denial "on a priori grounds that animals without a language can have
} 
the ethical implications of his conclusions, but some of it does. In one essay in particular Glock argues that, when considering how we ought to treat animals, the "rational procedure" to adopt is that of determining their "moral status ... on the basis of their possession or lack of morally relevant properties" - where the properties in question are, specifically, mental capacities (Glock 2013: 114).

Since Glock's mode of investigating the mental capacities of animals owes much to the philosophical methods of Wittgenstein, it is notable that his approach to animal ethics stands in stark contrast to the approaches of several contemporary moral philosophers who also claim to be inheritors of Wittgenstein's methods. Philosophers such as Cora Diamond, Raimond Gaita and Alice Crary, for example, explicitly reject the sort of approach that seeks to ground our moral attitudes, whether to animals or to humans, on the possession or non-possession of capacities identifiable in terms that are not already morally imbued. ${ }^{2}$ For these philosophers, the recognition of a person or an animal as requiring certain moral attitudes or responses from us is simply part and parcel of what coming to understand what people and animals are; in other words, the acknowledgement of people and animals as being morally significant is logically prior to the establishment of any specific capacities they may possess. ${ }^{3}$

The interest of this disagreement between Glock and other philosophers influenced by Wittgenstein extends far beyond questions of how a specifically Wittgensteinian approach to ethics should proceed: it bears upon issues of methodology in moral philosophy more generally. My starting point for discussing this debate and its ramifications is to examine an epilogue to the most directly relevant of Glock's essays. As I shall seek to show, it is possible to discern in that epilogue affinities between elements of Glock's thinking, on the one hand, and a thought

mental capacities at all, or at least the 'higher' mental capacities required for rational agency [and for moral status]" (Glock 2010: 384; cf. 2013: 120). Glock considers "the most important contemporary [or, at any rate, recent] proponent of lingualism" to be Donald Davidson (Glock 2017b: 166). Glock also takes issue with philosophers who deny (albeit not on lingualist grounds) that many or most animals feel pain; see, for example, Glock (2013: 121), where he cites Bermond (2003) and Harrison (1991) as cases in point.

${ }^{2}$ Although I shall not be discussing Gaita's work directly in this article, the key publication of his that I have in mind is The Philosopher's Dog (Gaita 2017). For a critical review of this, see Plumwood (2007).

${ }^{3}$ For a further Wittgenstein-inspired approach along these lines, focused primarily on our attitudes to persons but also with relevance to animals, see Chappell 2011. 
that has an important place in the work of Diamond, Gaita and Crary, on the other. Hence, despite his overt disavowal of the approach typified by Diamond, there is a sense in which Glock ends up where Diamond and others begin.

\section{Hans-Johann Glock on the Superior Moral Status of Human Beings}

The quotation in the title of my article occurs in what Glock terms a "Moral Epilogue (or: What Humans Owe to Each Other)" to his essay "Mental Capacities and Animal Ethics" (2013). The purpose of the epilogue is to affirm that even though, as he has argued in the main body of the essay, animals do have some moral status - a status that "depends to a large extent on their mental capacities" (2013: 138) - it does not follow that the moral status of animals is equivalent to that of human beings. Rather, the view to which Glock inclines maintains "that the moral status of humans is qualitatively distinct from that even of higher animals" and that "Our moral obligations towards each other are of a different order from our moral obligations towards [animals]" (138).

To give support to this inclination, Glock appeals to the fact that the modes of interpersonal communication that are possible between human beings far outstrip those which can occur between humans and even the most cognitively sophisticated of nonhuman animals. And this difference of communicative capacity, Glock maintains, has moral implications:

Our ability to interact with even the most advanced animals, to share ideas, responsibilities and aspirations with them, are severely restricted. And this provides succour to the idea that our obligations towards living human beings are of a different order from those towards animals. (Glock 2013: 140)

In making this link between communicative abilities and moral status, Glock recognizes that he must address the issues thrown up by so-called "marginal cases" - the sorts of cases that involve human beings who lack the normal range of cognitive, and hence also communicative, 
capacities. ${ }^{4}$ Especially relevant in this context are cases of human beings with severe intellectual impairments, so severe as to prevent their interacting with other people in precisely the ways that Glock has highlighted as being of moral significance. Acknowledging this point, Glock is keen to retain some distance between his own position and that of contractualists, who maintain, roughly, that we have moral obligations to one another, at least primarily, only insofar as we have all entered into a social contract. According to this contractualist view, moral obligations cannot apply - or, at any rate, cannot apply directly - to those who could not, even in principle, enter into such a contract, and this would include both animals and severely intellectually impaired human beings.

Glock responds to this contractualist position by accepting that its proponents are "right to link morality to human interaction" (141). Where these proponents go wrong, however, is "in thinking that this interaction must take the form of entering into some kind of agreement that is either explicit or at least explicable" (141). This is a mistake, Glock contends, because it conceives of the relevant forms of interaction in overly intellectualized terms. What is required for moral obligations to have the strength that they do between human beings, Glock insists, is not high-level verbal interaction, for other forms will suffice: "We should not underestimate the importance of facial expressions, gestures and bodily demeanours that are distinctly human in spite of being simple" (141). These are among the aspects of interpersonal human life in which intellectually impaired people can participate, yet they are unavailable to nonhuman animals. They thus facilitate the differentiation that Glock wishes to maintain between human beings, on the one hand, and all other animals, on the other. Another distinguishing factor that Glock mentions, albeit only in passing, is the importance of the fact that "we begat and gave birth to these individuals" (141). It is precisely in this connection that Glock adds the remark that "We are human beings, and we value human life" -

\footnotetext{
${ }^{4}$ Since the late 1970s, the term "marginal cases" has become pervasive in the philosophical literature, typically denoting infants, people with intellectual impairments and other "nonparadigmatic cases of human beings" (Narveson 1977: 164). The term is, or ought to be, controversial, given that it may readily be interpreted to imply that the people concerned are themselves merely "marginal humans" (Norcross 2004: 239 et passim) - a point that Crary notes (2010: 22). For the most part, I shall instead use more specific terms such as "intellectually impaired people".
} 
adding, further, that "If taking this lesson to heart makes one a speciesist, then so be it" (141).

The line of thinking that Glock is pursuing in the passage to which I have referred is philosophically intriguing. It raises questions which, given the necessary concision of the epilogue, it would be unreasonable of us to expect to be fully addressed therein. One question it raises is that of whether even the nonverbal modes of communication to which Glock refers are available to all the types of intellectually or otherwise impaired people that are relevant in this context. ${ }^{5}$ What might be said, for example, of someone whose impairments are so severe that she is incapable either of displaying or of registering the types of "facial expressions, gestures and bodily demeanours" at issue? Indeed, what should we say about people in a coma or in conditions of the sort that are commonly designated "persistent vegetative states" - or, for that matter, people who are dead? It would be surprising and unusual to suppose that no one can have any moral obligations towards the dead or the irreversibly comatose. Notwithstanding what some utilitarians have said, I presume that many of us would agree that such people's being no longer able to communicate does not extinguish their moral status. ${ }^{6}$

In cases such as these, a supporter of Glock's general line of thinking might invoke the notion of vulnerability that Glock mentions earlier in his essay. Although he is not favourably disposed to what he terms the "vulnerability approach" as a general account of why we should be respectful of nonhuman beings, Glock does consider this approach

\footnotetext{
${ }^{5}$ Another pertinent question would be whether we should concur with Glock's intimation that communication by means of "facial expressions, gestures and bodily demeanours" is unavailable to nonhuman animals. I say "intimation" (rather than assertion), for there is an ambiguity in Glock's phrasing: the phrase "facial expressions, gestures and bodily demeanours that are distinctly buman" (my emphasis) could be understood to mean either that facial expressions (etc.) are distinctly human (and hence cannot be displayed by members of other species) or that there are certain facial expressions (etc.) that are distinctly human and it is these that animals cannot display. Either way, the intimation seems to underestimate the relevant communicative capacities of at least some types of animal. Think, for example, of how much information is conveyed about a dog's emotional state by means of its bodily demeanour.

${ }^{6}$ Some utilitarian philosophers have maintained that anyone in a permanently unconscious state cannot be harmed (e.g. by harvesting their vital organs for transplantation or by switching off their life-support machine). Such philosophers include McMahan (2002), Rachels (1986), Singer (1995); for concise exposition, see Schumacher (2011: 40-43). The position of these philosophers concerning moral obligations towards such people becomes more complicated when, as in the case of McMahan (e.g. 2005: 354 et passim), they affirm the existence of "agentrelative" (as opposed to "intrinsic") reasons for treating someone in a particular way, but it would be a diversion for us to get embroiled in that issue here.
} 
applicable in some instances. Notably, in the case of plants, there would be no possibility of giving an account of our moral obligations towards them if we were to rely exclusively on the criterion of mental capacities, for there is no clear sense in which plants can have a mental life. Yet it does not follow that plants do not have needs, which, as Glock puts it, "can be either satisfied or frustrated" (116). To this extent, plants are vulnerable to harm in a sense that is not merely metaphorical, and this vulnerability gives us reason to regard them as possessing "some moral weight, however slight it may be and however low its place in a hierarchy of moral demands" (116).

So Glock's picture allows for something's having a moral status of which we ought to take notice, even if the thing in question lacks any means of communicating with us. The potential for applying this notion of vulnerability to cases such as those of permanently comatose people is, however, exceedingly limited. For, as we have just seen, in the absence of a mental life, Glock views vulnerability to harm as securing only a minimal moral status - a lowly position "in the hierarchy of moral demands". ${ }^{7}$ It remains the case that mental capacities must be in place to raise that moral status, and it is communicative capacities, of the sort possessed only by human beings without radical cognitive impairments, that carry the most moral weight. If we are not simply to ignore the moral status of people lacking any capacity to communicate, therefore, it looks as though, on Glock's account, a great deal of importance will have to be attached to the observation that it is we who "begat and gave birth to these individuals" and that human beings and human lives are among the things that we, as human beings ourselves, typically care about. $^{8}$

\footnotetext{
${ }^{7}$ It is even harder to see how a vulnerability approach could secure the moral status of dead people. Although it is not difficult to imagine how a corpse might be violated - by means of wanton mutilation, for example - or how a dead person might be slandered or otherwise insulted, it would require considerable work to spell out how a dead person is harmed by these or other actions in the relevant sense. For a discussion of posthumous harm in terms of vulnerability, see Belliotti 2012.

${ }^{8}$ Glock's point about the importance of begetting and giving birth in this context is, I presume, similar to a thought expressed by Tim Scanlon, who remarks that "The mere fact that a being is 'of human born' provides a strong reason for according it the same status as other humans. ... This tie of birth gives us good reason to want to treat them 'as human' despite their limited capacities" (Scanlon 1998: 185). Much could be said about Scanlon's use of the word "despite" in that last sentence, but this is not the place to discuss it.
} 
The reason I have used the phrase "We are human beings, and we value human life" in the title of this article is that I suspect it is one of the most important observations in Glock's essay, and certainly in the essay's epilogue. It can be viewed as constituting a move in a direction dramatically at odds with the main thrust of his essay. For the main thrust is that moral status depends on properties possessed by the thing to which the moral status is accorded, and the relevant properties are, Glock maintains, mental capacities. As we have seen, there are exceptions, such as in the case of plants, where some minimal moral status may be accorded on the basis of non-mental properties, but, in the case of animals, it is mental capacities that count.

When it comes, though, to resisting the temptation to suppose that there is nothing at all special about the moral status of human beings, Glock ends up, it seems, appealing to our kinship relations and to the fact - the brute fact - that we simply are human beings and we simply do care about human life. This observation is striking, and strikingly at odds with the essay's central argument, because it appears to allow the assumption that moral status must be grounded upon mental capacities to drop away. In place of this assumption, we are left with the basic truth that valuing human life is simply something we characteristically do. ${ }^{9}$

A further reason why Glock's assertion is striking is that it chimes closely with the sorts of assertions that we might expect from moral philosophers with whom, on other matters, Glock specifically wishes to take issue. Here I have especially in mind philosophers who would argue, first, that it is a mistake, or a confusion, to suppose that moral status can be grounded upon the possession of properties that are

\footnotetext{
9 As an anonymous reviewer for this journal has stressed, a way of strengthening Glock's position would be to read him as arguing that moral status is dependent upon mental or psychological capacities at the level of species rather than at the level of individuals. This reading would enable Glock to grant moral status to human beings who are incapable of communicating and to do so without resorting to the "brute fact" that I have just mentioned: Glock could maintain that it is by virtue of belonging to a species, the members of which normally do possess the "morally relevant properties", that severely impaired people possess moral status. I agree that this is a position worth examining. It is not, however, the one that Glock advocates. If it had been, then Glock would (surely) have made this explicit in his treatment of "marginal cases", both in his written work and in his comments following my oral delivery of a version of the present paper at the University of Hertfordshire in April 2019. Given the limitations of space, any examination of that alternative reading - or alternative line of argument - will have to await another occasion, though I am grateful to the reviewer for proposing it.
} 
describable in purely scientific terms, and second, that we ought instead to pay close attention to the ways in which moral evaluations are built into - are internally related to - our very understandings of what certain beings are. Notable instances of such philosophers include Cora Diamond and, more recently, Alice Crary. In the next section, I move to a discussion of the position exemplified by Crary, and in the section subsequent to that I bring the work of Diamond more overtly into the discussion.

\section{Alice Crary on Two Forms of Naturalism in Moral Philosophy}

The volume containing the essay by Glock that I have been citing also includes a contribution by Alice Crary, entitled "Eating and Experimenting on Animals: Two Issues in Ethics" (2013). Although Crary's essay makes no reference to Glock, it provides a fitting object of comparison, since the position for which she wishes to make conceptual space is defined by Crary in opposition to what, at least at first glance, may readily be regarded as the type of position that Glock's instantiates.

The distinction between the two positions in question is made by Crary in terms of contrastive metaphysical outlooks. Although both outlooks are forms of naturalism, they differ from each other with regard to the scope of what they each consider to fall within the category of the natural. The first outlook, which Crary dubs "traditional naturalism", equates "the real world" with "the ethically neutral world of the natural sciences" (Crary 2013: 323). From this perspective, animals and indeed human beings - are, in their metaphysical reality, entities that are "ethically neutral" or "ethically indifferent" $(323,324)$; their moral status is dependent on their metaphysical or ontological status - on what they really are - but what they really are is determined exclusively by non-moral factors. In this respect, the reality of what a human being or an animal is is external to ethics.

Crary views this traditional naturalism as going along with - or, at any rate, as frequently being accompanied by - a position that she, apparently following James Rachels, terms "moral individualism", which is the view "that any treatment a creature merits is a function of its 
individual capacities" (324). ${ }^{10}$ In the context of debates over how animals ought to be treated, moral individualists, as characterized by Crary, take a twofold stance. First, they maintain "that consistency obliges us to treat any capacities that we take to be morally significant in human beings to be likewise morally significant in those animals that possess them"; and second, they contend "that there are no morally significant capacities that are such that all humans possess them and no animals do" (324). The principal divergences among moral individualists hinge upon the capacities that are held to be of moral significance. For utilitarians such as Peter Singer, the crucial capacity is sentience, the capacity to feel pleasure and pain; meanwhile, for rights-based theorists such as Tom Regan, it is the "capacity for subjecthood" (Crary 2016: 125; see also 2013: 324). ${ }^{11}$

Where these moral individualist theories come unstuck, Crary avers, is precisely in connection with the types of cases of cognitive impairment to which I referred earlier. The contention that an individual's moral status depends upon the possession of certain physiological or psychological capacities, Crary remarks, "flies in the face" of two very widely held ideas: first, "that seriously impaired human beings merit special solicitude in virtue of their special susceptibility"; and second, "that there is something particularly hateful about intentionally injuring the seriously impaired, something that the fact that these human beings may be unable to understand the injuries inflicted on them not only doesn't mitigate but aggravates" (2013: 326). In light of these observations, Crary contends that moral individualism results in "a distorted image of value" both in human and in animal life (326).

In view of these problems, some advocates of animal welfare, while continuing to operate within a traditionally naturalist paradigm, have developed accounts of the moral status of animals that depart from moral individualism. Notable among these advocates are ethicists who, though locating themselves within a Kantian tradition, seek to extend

${ }^{10}$ Compare Rachels (1990: 173): "The basic idea [of moral individualism] is that how an individual may be treated is determined, not by considering his group memberships, but by considering his own particular characteristics." Crary cites Rachels as a "self-avowed moral individualist" in Crary (2010: 20; 2016: 124). For a defence of moral individualism, see McMahan 2005.

${ }^{11}$ Regan's own preferred term is "subject-of-a-life" (Regan 2004: xxii-xxiii, 243-248), but this is commonly paraphrased in terms of "subjecthood" in secondary literature (e.g. Warren 1997: 107). 
the scope of moral concern beyond the sphere of specifically rational agents, which has been the sphere typically privileged by Kantian theory. Exceeding this restrictive model, Kantians such as Christine Korsgaard and Allen Wood have sought to enlarge the sphere of moral concern to encompass the interests of certain non-rational creatures as well, which include not only pre-rational or severely cognitively impaired human beings but also nonhuman animals. ${ }^{12}$

Rather than striving to refute Kantian approaches directly, Crary's strategy is to undermine the assumption that traditional naturalism must be adopted as the background metaphysical outlook against which moral theorizing takes place. Her means of doing this is, for the most part, to put forward an alternative outlook and to invite us to reflect upon whether we have any good reasons for rejecting it. The alternative outlook in question is termed by Crary "broad naturalism" in the essay to which I have been referring. Elsewhere, including her recent book Inside Ethics, she calls it a "wider conception of objectivity", in contrast to the "narrower conception of objectivity" that she identifies with the "hard" metaphysics of traditional naturalism (2016: 34 et passim). ${ }^{13}$ I presume she wishes to retain an allegiance to naturalism to avoid any suspicion that something supernatural or religious is being invoked to support the ethical perspective she is offering (though in a recent exchange with Stanley Hauerwas, Crary has been willing to acknowledge affinities between her own perspective and Hauerwas's more theologically motivated one $\left.{ }^{14}\right)$. The terms "broad" and "wider" are used

\footnotetext{
${ }^{12}$ For discussion of Korsgaard, see Crary (2016: 25-35). Relevant ideas from Wood are advanced in Wood 1998. It should be noted that the relation between Kantianism and moral individualism is not straightforward. Traditional Kantians are moral individualists inasmuch as they hold that it is an individual's possession of rational agency that confers moral status upon the individual concerned. The Kantians to whom Crary is responding, however, seek to extend moral status to non-rational creatures by appealing to those creatures' characteristic interests. For my purposes here, it is Crary's response that is important, rather than the minutiae of the Kantian relation to moral individualism.

${ }^{13}$ Crary finds the notion of reality as something "hard" in Korsgaard (1996: 1-5); see Crary (2010: 42, 49 n.78). Korsgaard herself adapts it from Nietzsche's talk of "oneself as a hard, recalcitrant, suffering material" (The Genealogy of Morals 2.18, quoted in Korsgaard 1996: 1).

${ }^{14}$ See, for example, Crary (2018): "My book urges that pursuit of the kind of undistorted empirical understanding of human beings' and animals' lives that we seek in ethics requires openness to investigating ethically charged attitudes that we find expressed in, say, 'work across different fields in the humanities as well as in literature and other arts' ([Crary 2016:] 3), and Hauerwas is right that it follows from my larger argument that this openness should be construed to involve a posture of willingness to explore, inter alia, non-neutral perspectives that we encounter in theology and the study of religion."
} 
to indicate that the outlook is sufficiently capacious to allow that moral properties, and hence moral status, are internal to the ontological or metaphysical conception of what animals are - and indeed of what human beings are as well. Putting the point in the form of a rhetorical question, Crary asks: "Why shouldn't we say, in a manner that repudiates the terms of traditional naturalism, that there is an entirely straightforward (i.e., not merely practical) sense in which the recognition that a creature is an animal is by itself morally significant?" (2013: 328).

One way of making the contrast that Crary is herself making is, then, to think of it, again, in terms of internal versus external conceptual relations. For the traditional naturalist, whether moral individualist or Kantian, a being's moral status must be inferred from its possession of certain metaphysical or biological properties, which, though "morally relevant" (to use Glock's term), are not themselves of any intrinsic moral significance. For the broad naturalist or wider objectivist, meanwhile, there is no inference involved: rather, coming to deepen one's understanding of what a being of a certain sort is will, necessarily, include coming to a deeper understanding of its moral status - and hence of what our moral obligations towards it are. In this sense, the relation between metaphysics and ethics is internal. Or, in other words, "human beings and animals are inside ethics" (Crary 2016: 35). ${ }^{15}$

A consequence that, according to Crary, follows from the adoption of a broad naturalist outlook is the availability of, or perhaps the requirement for, alternative methods of philosophical argumentation. In the specific case of animal ethics, for instance, the traditional naturalist outlook places the emphasis on seeking evidence that animals possess certain physiological or psychological capacities that are also possessed by human beings - or, at any rate, by human beings who do not fall into the category of "marginal cases". Broad naturalism, by contrast, emphasizes methods of bringing one's interlocutor to see, in a more holistic manner, the kinds of beings that animals are and the kinds of lives they lead. My use of the term "holistic" is intended here to intimate Crary's conception of rationality as including, rather than excluding,

\footnotetext{
${ }^{15}$ Might it be possible to read Glock as sharing this view of an internal relation between metaphysics and ethics? The fact that he speaks of our making a decision about "the moral status of animals on the basis of their possession or lack of morally relevant properties" (2013: 114, my emphasis), and of animals' moral status depending "to a large extent on their mental capacities" (138), suggests that the conceptual relation is inferential rather than internal. I thank an anonymous reviewer for pressing me on this point.
} 
affective and imaginative responses to the world (see, e.g., Crary 2016: 206-212).

Importantly, for Crary and for others who take a similar position to hers, this shift of emphasis from a narrower to a wider conception of rationality gives a greater role, in moral philosophizing, to the cultivation of the moral imagination through engagement with works of art, including poetry and narrative literature, for it is precisely in works of these sorts that the lives of animals are able to be displayed, or portrayed, in ways that bring out their rich complexity. In place of a taxonomy of capacities, whether physiological or psychological, the reader is offered a depiction of a form of life, which, in some cases, can engender a heightened sense of existential kinship and community with the animals in question - an effect that the more abstract taxonomizing of capacities promoted by traditional naturalist approaches is less likely to evoke.

Crary has her own literary examples that she adduces in several of her publications, but she also looks to the work of forerunners such as Raimond Gaita and, most notably, Cora Diamond as exemplars of this turn towards literature in the cause of a broad naturalist metaphysical outlook. Since a large part of my purpose in this article is to bring into relief certain features of the approach to animal ethics typified by Glock, and since Glock contrasts his own approach, at least at one point, with that of Cora Diamond, I shall here focus on that particular contrast.

\section{Glock's Rejection of Diamond's “Virtue Theory”}

In a notebook entry from 1939 or 1940, Wittgenstein remarks of his contemporaries that they tend to regard scientists as being "there to instruct them", and "poets, musicians etc." as providing mere entertainment. "That the latter have something to teach them; that never occurs to them" (CV: 42e). This remark encapsulates the anti-scientistic bent of Wittgenstein's thinking, which coheres with an appreciation of how the arts and humanities can enhance our understanding of life and the world. It is an appreciation that resonates strongly with the turn towards 
literature that we find in the work of Wittgenstein-influenced philosophers such as Crary and Diamond. ${ }^{16}$

A place where Diamond is cited by Glock, albeit briefly, is a passage in which Glock is differentiating his own approach to animal ethics from that of others. Having observed that some ideologically driven theorists tend to mould their "factual and conceptual claims about animal minds" to suit their preconceived "views on the moral status of animals" (Glock 2013: 114), Glock remarks that he discerns a vice similar to this in the work of certain virtue ethicists. "According to them", Glock writes, "our treatment of animals should not be guided by rational argumentation concerning the moral significance of features possessed by animals". Instead, Glock continues, such virtue ethicists suppose it to be "a matter of our moral experience, in particular of the concern we have with leading a virtuous life, which will create an indescribable pull against cruelty towards animals" (2013: 114). And it is here that Glock cites, as exemplifying this vice, two chapters from Diamond's book The Realistic Spirit (1991) plus a couple of pages from an essay by Rosalind Hursthouse (2000). The problem that Glock sees with the tendency in question consists in the portrayal of "our moral thinking and our moral lives as more self-regarding and egocentric" than it either ought to be or, indeed, is (Glock 2013: 114).

In the case of Hursthouse, the very title of her essay - "The Virtue Ethics Defence of Animals" - indicates that Glock is right to identify her as a virtue ethicist. Whether she is guilty in her approach to animal ethics of the kind of egocentrism of which Glock accuses her is, however, doubtful. Admittedly, in the passage that Glock cites, Hursthouse is describing in autobiographical terms how she came to be "converted to vegetarianism" (2000: 165), but the self-referential nature of the passage is not gratuitous. It is intended to illustrate the broader point that, as Hursthouse puts it, although "rational argument in morals has an important role to play, and is sometimes decisive in changing people's minds", there are occasions when it needs to be "aided by a shift of moral vision" (ibid.). For Hursthouse, this shift was instigated by her reading Stephen Clark's book The Moral Status of Animals (1977), which, she reports, gradually changed her "perception of the moral

\footnotetext{
${ }^{16}$ See also the discussions of literature and film by, for example, D. Z. Phillips (1982, 1986, 2006) and Stephen Mulhall $(2009,2016)$. An early pioneer in this regard was Peter Winch (e.g. Winch 1965).
} 
landscape and where [she] and the other animals were situated in it" (Hursthouse 2000: 165-166). What Hursthouse is not claiming is that, in the context of animal ethics, rational argument should be replaced by an appeal to experience. Instead, she is observing that it was a specific style of argumentation, exemplified by Clark, that enabled her to reorient her moral perspective. And the change that was engendered in Hursthouse's life did not involve a fixation on her own virtuous development as opposed to acquiring a clear view of the features of animals that warrant their being treated in a respectful manner; on the contrary, it was the change in moral perspective that enabled her to see the full force of the kinds of arguments that rely on pointing out those morally relevant features, such as the capacity to suffer pain, feel terrified and so forth.

So it appears that Glock is unfair in ascribing to Hursthouse, on the basis of the passage cited, the kind of perniciously "self-regarding and egocentric" preoccupations to which he objects. And in the case of Cora Diamond, it is not even clear why he identifies her as a virtue theorist at all. ${ }^{17}$ In fact, as I shall now argue, there are good reasons for seeing a strong affinity between Glock's own observation that "We are human beings, and we value human life" and Diamond's analysis of human and animal ethics.

The two chapters of Diamond's that are cited by Glock are her "Eating Meat and Eating People" (1991, ch. 13) and "Experimenting on Animals: A Problem in Ethics" (1991, ch. 14). There are obvious reasons why these two chapters are pertinent to Diamond's views on the ethical treatment of animals. Also relevant, however, is her essay "Anything but Argument", first published in 1982 and republished as Chapter 11 in the book that Glock cites. "Anything but Argument" is especially relevant in this context because not only is it directly concerned with issues of method in moral philosophy, but it adopts as its principal objective the defence of precisely the style of argumentation exemplified in Stephen Clark's The Moral Status of Animals - the very book that, as I have noted, Hursthouse praises for having initiated a shift in her moral vision.

Diamond's interest in defending Clark's approach was prompted by a critical review of his book by the Kantian philosopher Onora O’Neill

${ }^{17}$ In fairness to Glock, I should note that, in discussion, he has acknowledged that labelling Diamond as a virtue theorist was a mistake. 
(1980). ${ }^{18}$ What O'Neill took exception to was what she perceived as Clark's failure to engage in the debate over "the metaphysical grounds that determine who or what may have moral standing" (O’Neill 1980: 446). Instead of doing this, Clark had appealed primarily to the notion of kinship between humans and animals: not so much in the sense that we have a common biological ancestry with them, but rather in the sense that we do in fact share, and have shared throughout our history, large portions of our lives with animals. In short, Clark advocates an expanded conception of our sense of community, in which animals are appreciated as members of that community who are worthy of greater respect than is routinely exhibited in most contemporary societies: "Not a community formed in myth or history by a signed contract between adult and autonomous persons", Clark writes, "but a community, a biocoenosis which has evolved its own regulating factors, its own enormously varied ways of life over several thousand million years" (Clark 1977: 31). What Clark does not do - and what O'Neill thinks he really ought to have done if he is to participate in serious philosophical argument - is pick out certain properties or features of animals, such as sentience or some other mental or behavioural capacity, and to offer reasons for regarding possession of these as according a specific moral status to the animals in question. Noteworthy for our purposes here is the resemblance between this objection to Clark on the part of O'Neill, and Glock's objection to the approach exemplified by Hursthouse and Diamond.

Diamond takes O'Neill's criticisms of Clark as a starting point for exploring the more general question of what count as legitimate methods of convincing someone to revise his or her attitudes, especially moral attitudes, in a particular direction. Among the methods for which Diamond wishes to make space, and which O'Neill wishes to preclude as philosophically irrelevant, is the kind of transformation of sensibilities to which great works of literature can make a significant contribution. Citing the lyric poetry of Wordsworth and the novels of Charles Dickens as salient examples, Diamond describes how such works can "lead their audience to new moral responses" (1991: 297). With reference to certain of Dickens's novels in particular, Diamond proposes that central to their aim is the changing of social attitudes towards children by enabling

${ }^{18} \mathrm{My}$ discussion in this and the next two paragraphs echoes a longer treatment of the topic in Burley (2017: 105-108). 
readers to more fully recognize children as possessors of a distinct outlook on the world. According to Diamond, what Dickens along with many other great authors provides are "paradigms of a sort of attention" - forms of description with the power "to enlighten the understanding and ameliorate the affections" (299).

Diamond's point about this capacity of literature to direct our attention and enhance our affective responses is illustrated in her earlier essay, "Eating Meat and Eating People" (first published in 1978), which is one of the two chapters that Glock directly cites. The point of departure in that essay is what Diamond regards as a misguided style of argumentation, purportedly in favour of animal welfare, that is typified by authors who invoke the notion of speciesism. What these authors tend to do, Diamond explains, is to seek out resemblances between animals and human beings - or between certain animals and certain human beings - and to argue that, just as forms of discrimination such as racism and sexism involve making arbitrary distinctions between human groups, so disregarding the interests of animals in not being experimented upon or killed for food also involves arbitrary discrimination. It involves such discrimination because, when due attention is given to the morally relevant features or capacities of animals, we see that, to a great extent, these are shared with human beings; indeed, compared to humans in the "marginal cases" category, many animals are apt to possess the relevant features to a higher degree, and hence it would be inconsistent for us to accord them a lower moral status than, for example, severely intellectually impaired human beings (see Diamond 1991: 319-320). What Diamond finds objectionable about this argumentative approach is that it "makes it hard to see what is important either in our relationships with other human beings or in our relationship with animals" (321), and the bulk of her essay is an attempt to elaborate this point. ${ }^{19}$

One way of encapsulating Diamond's central observation would be to say that, in her view, what the style of argumentation to which she objects misses is the importance of what is expressed in Glock's phrase, "We are human beings, and we value human life". In other words, it misses the fact that there is something morally significant about simply being human, and to overlook this fact is liable to distort one's whole

${ }^{19}$ To make the point more clearly, the words that Diamond italicizes in the foregoing quotation should probably have been "both ... and" rather than "either ... or". 
approach to trying to extend the range of moral concern to encompass animals. In the case of eating meat, for example, Diamond holds it to be of no small significance that, for many people, a crucial feature of their understanding of the differences between humans and animals will be the recognition that humans - unlike animals - are not something to be eaten. By saying this, Diamond is not expressing approval for the eating of meat; she takes herself to be offering an important reminder about the concept (or "our notion" 20 ) of a human being - and about the concept of a nonhuman animal.

Having offered these reminders, Diamond turns her attention to the kind of argumentative strategy that might replace that which involves looking for biological or psychological capacities shared by humans and animals and then claiming that these capacities carry moral weight. What Diamond's proposed alternative consists in includes, as a central element, the invocation of poetic representations of how individual animals may be perceived as sharing with us not specific properties or capacities that might be characterized in scientific terms, but rather the condition of being the possessor and inhabitant of a life. With reference to Walter de la Mare's poem "Titmouse", for example, Diamond remarks that de la Mare's description of the bird as a "tiny son of life" conveys a relationship of fellowship - the recognition on the poet's part of a "fellow creature" who may, without undue anthropomorphism or sentimentality, "be sought as company" (Diamond 1991: 328, 329).

In a similar vein is Robert Burns's poem "To a Mouse", in which Burns, addressing the mouse whose nest he has inadvertently upturned with a plough, describes himself as "thy poor earthborn companion, / An' fellow mortal" (quoted in Diamond 1991: 329). To address a mouse in these terms is not - or is not primarily - to acknowledge that mice have certain biological or psychological capacities in common with human beings. Rather, it is, again, to accentuate the common possession of a life, which brings with it a susceptibility to contingencies that can turn one's life upside down. It is - to invoke Stephen Clark's term once more - to extend the reach of the concept of community to embrace animals, fellow creatures, who may otherwise have been conceptualized in other terms.

\footnotetext{
${ }^{20}$ See, for example, Diamond (1991: 324) on "our notion of human beings". I argue for the culturally contingent nature of this notion in Burley 2016.
} 
This use of literary examples undoubtedly does place a certain weight on the cultivation of moral experience, or, as Diamond is wont to put it, upon the capacity of literature "to enlarge the reader's moral and emotional sensibilities" (1991: 297). But to suppose that this is somehow connected with an unhealthily "self-regarding and egocentric" portrayal of "our moral thinking and our moral lives" (Glock 2013: 114), is to get things seriously wrong.

\section{Concluding Remarks}

If I were to take issue with the forms of argumentation that we see in the work of Wittgenstein-influenced moral philosophers such as Diamond and Crary, and indeed Raimond Gaita, it would be on the grounds that they deliberately select their examples - whether literary or from real life - to promote a specific moral vision while, at the same time, implying that their examples are revealing deep truths about the nature of reality. Crary is especially upfront about this claim to be discerning deep truths when she talks about "objectivity" and a "metaphysical outlook". She considers the examples to which she appeals to be exemplifying not merely possible moral perspectives, but how things really, objectively, are.

Regardless of whether one's own moral values do or do not chime with those of Crary, we have good reason to be suspicious of such claims to objective metaphysical insight. Although it would require more space than I have here to substantiate the point, it seems to me that Avner Baz is on the right lines when, in a recent response to Crary's book, he reminds us that, in moral discourse, terms such as "should" and "ought" typically have "the force, not of stating an objectively establishable fact, but of urging someone, or calling upon her, to do what we believe, 'know in our heart,' but cannot prove, to be the right thing for her to do" (Baz 2018). Crary, it should be noted, is making no claims about the possibility of proving the correctness of her or anyone else's moral judgements; yet it is in light of the sort of conceptual observations made by Baz that we are liable to lose our grip on the sense that Crary is trying to attach to the notion of objectivity in moral attitudes. In place of such claims to objectivity, a Wittgenstein-inspired moral philosophy would do well to follow D. Z. Phillips in seeking to do conceptual justice to the "heterogeneity of moral beliefs" (1992: 27, 105), by 
expanding the repertoire of examples rather than privileging a one-sided diet.

Be that as it may, Diamond and Crary are making important points in response to the forms of argument that suppose animal ethics to be a matter of analysing the capacities of animals to determine which of them are relevantly similar to capacities possessed by human beings and, on that basis, arriving at a judgement about how, in moral terms, the animals ought to be treated. Among those important points is the observation that there is - or, for most people, there typically is something morally significant about simply being human, and one of the ways in which we may see this is in reflecting upon precisely the kinds of cases of severely cognitively impaired people that are routinely termed "marginal cases" in the philosophical literature. What philosophers such as Diamond, Crary and Gaita have noticed is that the natural impulse to regard these cases as especially deserving of moral care and consideration cannot adequately be accounted for by reference to specific capacities the possession of which endows their possessors with a certain moral status. Hence, insofar as we do regard people with severe cognitive impairments as deserving of special consideration, we have reason to reject the kinds of accounts that appeal to the capacities of individuals. $^{21}$

Although I hesitate to draw any broad-ranging conclusions about how moral philosophizing in relation to animals ought to proceed, my observations in this article lend a greater legitimacy to the methods of argumentation deployed by Diamond, Crary and Gaita than they might otherwise have been accorded. Glock, as we have seen, recognizes the difficulty of doing conceptual justice to the attitude of concern towards people with cognitive impairments in terms of a capacities approach. It seems that this recognition on his part is what prompts him, when looking for a well-motivated reason for regarding human beings as having a higher moral status than that of animals, to affirm that, when it comes down to it, it just is the case that, for the most part, we care about our fellow humans. In coming to this affirmation, there is a sense in which Glock has reached the point from which the respective arguments

\footnotetext{
${ }^{21}$ The qualification "of individuals" is important here, in light of what I said in footnote 9 above. I should also add that I am leaving open the possibility (since we know all too well that it is more than a mere possibility) that a sense of responsibility for the well-being of cognitively impaired people is not universally shared.
} 
of Diamond, Crary and Gaita begin. Having begun at that point, these latter philosophers take their inquiries into animal ethics in directions very different from that of looking for morally relevant mental capacities that animals have in common with human beings. Notwithstanding Glock's eagerness to distance himself from their methods, and his dislike of appeals to moral experience and imagination, what I have contended is that there may nevertheless be a lurking affinity in the shared observation that, as Glock so straightforwardly and yet so perceptively puts it, "We are human beings, and we value human life". ${ }^{22}$

\section{References}

Baz, A., 2018. "Response: On Alice Crary's Inside Ethics”. In: Syndicate: Inside Ethics. Available online at: https://syndicate.network/symposia/philosophy/inside-ethics/ (accessed 30 January 2019).

Belliotti, R. A., 2012. Posthumous Harm: Why the Dead are Still V ulnerable. Lanham, MD: Lexington Books.

Bermond, B., 2003 [1997]. “The Myth of Animal Suffering”. In: S. J. Armstrong and R. G. Botzler, eds., The Animal Ethics Reader. London: Routledge, 79-85.

Burley, M., 2016. "Eating Human Beings: Varieties of Cannibalism and the Heterogeneity of Human Life". Philosophy 91 (4), 483-501

Burley, M., 2017. “The Happy Side of Babel': Radical Plurality, Narrative Fiction and the Philosophy of Religion". Method and Theory in the Study of Religion 29 (2), 101-132.

Chappell, T., 2011. "On the Very Idea of Criteria for Personhood". Southern Journal of Philosophy 49 (1), 1-27.

Clark, S. R. L., 1977. The Moral Status of Animals. Oxford: Oxford University Press.

Crary, A., 2010. "Minding What Already Matters: A Critique of Moral Individualism". Philosophical Topics 38 (1), 17-49.

Crary, A., 2013. "Eating and Experimenting on Animals: Two Issues in Ethics". In K. Petrus and M. Wild, eds., Animal Minds and Animal Ethics: Connecting Two Separate Fields. Bielefeld: transcript, 321-354.

Crary, A., 2016. Inside Ethics: On the Demands of Moral Thought. Cambridge, MA: Harvard University Press.

\footnotetext{
${ }^{22}$ An abridged version of this paper was presented at a workshop on the theme of "Animal Minds and Animal Ethics" at the University of Hertfordshire in April 2019. I am grateful to participants in that workshop for productive discussion, especially Hanjo Glock, and to the organizer, Constantine Sandis. My gratitude is extended to no fewer than four anonymous reviewers for this journal, whose respective assessments provided both encouragement and constructive criticism.
} 
Crary, A., 2018. "Reply: Thoughts on Cats and Theology". In: Syndicate: Inside Ethics. Available online at:

https://syndicate.network/symposia/philosophy/inside-ethics/ (accessed 26 January 2019).

Diamond, C., 1991. The Realistic Spirit: Wittgenstein, Philosophy, and the Mind. Cambridge, MA: MIT Press.

Gaita, R., 2017 [2002]. The Philosopher's Dog. Abingdon: Routledge.

Glock, H.-J., 2010. “Animal Agency”. In: T. O'Connor and C. Sandis, eds., A Companion to the Philosophy of Action. Oxford: Wiley-Blackwell, 384-392.

Glock, H.-J., 2012. “Animals: Agency, Reasons and Reasoning”. In: J. Nida-

Rümelin and E. Özmen, eds., Welt der Gründe. Hamburg: Meiner, 900-913.

Glock, H.-J., 2013. "Mental Capacities and Animal Ethics". In: K. Petrus and M.

Wild, eds., Animal Minds and Animal Ethics: Connecting Two Separate Fields.

Bielefeld: transcript, 113-146.

Glock, H.-J., 2016. “Aspect-Perception, Perception and Animals: Wittgenstein and Beyond". In: G. Kemp and G. M. Mras, eds., Wollheim, Wittgenstein, and Pictorial Representation: Seeing-As and Seeing-In. Abingdon: Routledge, 77-100. Glock, H.-J., 2017a. “Animal Minds". In: B. P. McLaughlin, ed., Philosophy: Mind. Farmington Hills, MI: Gale, Cengage Learning, 327-351.

Glock, H.-J., 2017b. "Wittgenstein and Davidson on Animal Minds". In: C. Verheggen, ed., Wittgenstein and Davidson on Language, Thought, and Action. Cambridge: Cambridge University Press, 159-185.

Glock, H.-J., 2018. “Animal Rationality and Belief”. In: K. Andrews and J. Beck, eds., The Routledge Handbook of Philosophy of Animal Minds. Abingdon:

Routledge, 89-99.

Harrison, P., 1991. "Do Animals Feel Pain?” Philosophy 66 (255), 25-40.

Hursthouse, R., 2000. "The Virtue Ethics Defence of Animals”. In: R. Hursthouse, Ethics, Humans and Other Animals: An Introduction. Abingdon: Routledge, 145166.

Korsgaard, C. M., 1996. The Sources of Normativity. Cambridge: Cambridge University Press.

McMahan, J., 2002. The Ethics of Killing: Problems at the Margins of Life. Oxford: Oxford University Press.

McMahan, J., 2005. "'Our Fellow Creatures"'. Journal of Ethics 9 (3-4), 353-380. Mulhall, S., 2009. The Wounded Animal: J. M. Coetree and the Difficulty of Reality in Literature and Philosophy. Princeton, NJ: Princeton University Press.

Mulhall, S., 2016. On Film, 3rd ed. Abingdon: Routledge.

Narveson, J., 1977. “Animal Rights”. Canadian Journal of Philosophy 7 (1), 161-178.

Norcross, A., 2004. "Puppies, Pigs, and People: Eating Meat and Marginal Cases". Ethics 18 (1), 229-245.

O’Neill, O., 1980. "Review of Stephen Clark, The Moral Status of Animals". Journal of Philosopby 77 (7), 440-446.

Phillips, D. Z., 1982. Through a Darkening Glass: Philosophy, Literature, and Cultural Change. Oxford: Blackwell. 
Phillips, D. Z., 1986. R. S. Thomas: Poet of the Hidden God. Allison Park, PA: Pickwick.

Phillips, D. Z., 1992. Interventions in Ethics. Albany, NY: State University of New York Press.

Phillips, D. Z., 2006. From Fantasy to Faith: Morality, Religion and Twentieth-Century Literature, 2nd ed. London: SCM Press.

Plumwood, V., 2007. "Human Exceptionalism and the Limitations of Animals: A Review of Raimond Gaita's 'The Philosopher's Dog"'. Australian Humanities Review 42. Available online at: http:/ / australianhumanitiesreview.org/2007/08/01/human-exceptionalismand-the-limitations-of-animals-a-review-of-raimond-gaitas-the-philosophersdog/ (accessed 29 August 2020).

Rachels, J., 1986. The End of Life: Euthanasia and Morality. Oxford: Oxford University Press.

Rachels, J., 1990. Created from Animals: The Moral Implications of Darvinism. Oxford: Oxford University Press.

Regan, T., 2004 [1983]. The Case for Animal Rights, 2nd ed. Berkeley: University of California Press.

Scanlon, T. M., 1998. What We Owe to Each Other. Cambridge, MA: Harvard University Press.

Schumacher, B. N., 2011. Death and Mortality in Contemporary Philosophy, trans. M. J. Miller. Cambridge: Cambridge University Press.

Singer, P., 1995. Rethinking Life and Death: The Collapse of Our Traditional Ethics.

Oxford: Oxford University Press.

Warren, M. A., 1997. Moral Status: Obligations to Persons and Other Living Things. Oxford: Oxford University Press.

Winch, P., 1965. "The Universalizability of Moral Judgements”. The Monist 49 (2), 196-214.

Wittgenstein, L., 1998. Culture and V alue: A Selection from the Posthumous Remains, ed.

G. H. von Wright and H. Nyman, rev. by A. Pichler, trans. P. Winch.

Oxford: Blackwell. [CV]

Wood, A. W. 1998. "Kant on Duties Regarding Nonrational Nature”. Aristotelian Society Supplementary Volume 72, 189-210.

\section{Biographical Note}

Mikel Burley is Associate Professor of Religion and Philosophy at the University of Leeds, UK. His previous articles in the Nordic Wittgenstein Review are "Contemplating Evil", NWR 1 (2012), 35-54, and "Reincarnation and the Lack of Imagination in Philosophy", NWR 4, no. 2 (2015), 39-64. His recent books include $A$ Radical Pluralist Philosophy of Religion: CrossCultural, Multireligious, Interdisciplinary (Bloomsbury 2020) and the edited volume, Wittgenstein, Religion and Ethics: New Perspectives from Philosophy and Theology (Bloomsbury 2018). 